\title{
LOOKING WITH ONE EYE CLOSED: THE TWILIGHT OF ADMINISTRATIVE LAW
}

\author{
RoNALd A. CASS*
}

\section{Judge Smith's Substance, Administrative Law's Process}

In an article published recently in this Journal, Judge Loren Smith calls for a change in tle focus of thinking and writing about administrative law. ${ }^{1}$ Judge Smith asks that we shift from our dominant concern over the process of administrative decisionmaking toward a concern over the substance of administrative action instead.

His article lias two thiemes. Judge Smith first stresses that administrative action inevitably takes place in a political milieu. Not all administrative decisions are designed to be acts of political will, freed from constraints otlier tlian political power. But inany are, and all administrative decisions must be viewed in the context of larger issues soluble only by the fiat of subjective political judgment. To lose sight of tlie political sea tliat spawns, defines, and checks administrative activity, Judge Smith argues, is to mistake the fundannental nature of the administrative enterprise.

Second, Judge Smith contends that legislators, judges, and commentators who liave shaped administrative law in America have made just this mistake. ${ }^{2}$ The story of administrative law told by Judge Smitli is the development of elaborate, court-like procedures for nearly all administrative decisions. The procedures build a record of facts and arguinents upon whicli decision must be based, thus confining tlie decisionmaker's discretion and facilitating judicial supervision. ${ }^{3}$ Under this regime, the rectitude of administrative decisions is tested not by whether they respond to the current political majority, or whether they are intrinsically good. Ratlier, tlie decisions must be made as courts would make themthey inust follow logically from factual predicates established in the decision process to a single, objectively correct result. ${ }^{4}$ Judge Smith finds that, for a broad range of admmistrative tasks, these court-like proce-

* Professor of Law, Boston University.

1. Smith, Judicialization: The Twilight of Administrative Law, 1985 DUKE L.J. 427.

2. See id. at 429-32 (summarizing distinction between "political" and "legal" decisionmaking, and asserting that modern administrative law fallaciously confuses the two).

3. See id. at 441, 445-47 (discussing how the involvement of more actors in decisionmaking by creation of a "record" encourages application of creativity-restraining legal processes).

4. See id. at 430. 
dures and associated constraints are incompatible with fidelity to political command and inimical to wise resolution of the problems that have devolved upon administrators. To combat "over-proceduratization," Judge Smith sounds the trumpet call for a rediscovery of the moral, pohtical and institutional values that ought to be the benchmarks for agency action. 5

There is much in Judge Smith's argument that deserves seconding. Undeniably, political processes play an enormous role in the creation and operation of administrative agencies. Equally undeniable is the importance of understanding that role and of keeping it in mind when discussing any issue of administrative process. Even a casual perusal of the volumes in which judges and scholars write reveals ample evidence that Judge Smith's admonition often goes unheeded. Judges and authors freely prescribe processes for admmistrative decisionmaking without reference to their own normative assumptions and without serious attention to the political judgments that define the decision to which the procedures will be appled. ${ }^{6}$ Increasing insulation of administrative decisions from political influence is a frequent recominendation. ${ }^{7}$ Champions of this approach do not always rest their process recommendation on evidence that the asserted beneficial effects will in fact flow from such processes, much less on evidence that a political consensus supports thein. ${ }^{8}$ Argument about process issues inore often proceeds from models of how the administrative process ought to work-models that neither reflect political consensus, nor rest on fully specified theories. ${ }^{9}$

Of course, Loren Smith is not the first to argue that American adininistrative processes are "over-judicialized."10 Judge Smith's article

5. Id. at 466 (urging "fundamental reappraisal of our governmental system," including reevaluation of constitutional separation of powers to reflect the modern administrative state).

6. See the discussion in Cass, Allocation of Authority in Bureaucracies: Empirical Evidence and Normative Analysis, 66 B.U.L. REV. 1 (1986) (forthcoming).

7. See, e.g., Davis, Judicialization of Administrative Law: The Trial-Type Hearing and the Changing Status of the Hcaring Officer, 1977 DukE L.J. 389, 406-08 (discussing "common deficiency" of state and federal administrative procedure reform proposals of allowing political actors final review over administrative adjudications); Fauver, An Agenda for Investigation: Should the APA Be Amended to Provide Standards for Agency Review of Administrative Trials?, 1973 DUKE L.J. $135,142-43$ (advocating uniform standards for agency review of administrative adjudications); Marzloff, Delay in Review of Initial Decisions: The Case for Giving More Finality to the Findings of Fact of the Administrative Law Judge, 35 WASH. \& LEE L. REV. 393, 416-17 (1978) (urging that, because of ALJ's greater legal expertise, political impartiality, and limits on agency time and objectivity, ALJ findings of fact should not be reversed upon agency review unless "clearly erroneous").

8. See Cass, supra note 6.

9. See Cass, Models of Administrative Action, 72 VA. L. REv. 363 (1986).

10. See, eg., Pops, The Judicialization of Federal Administrative Law Judges: Implications for Policymaking, 81 W. VA. L. Rev. 169, 205-06 (1979); Scalia, The ALJ Fiasco: A Reprise, 47 U. CHI. L. REv. 57 (1979) (arguing that appointment and promotion procedures for ALJs prevent efficiency in administrative adjudication). For a discussion of the problems of judicial intrusion into institu- 
cites some of the prior literature and aptly notes that several related arguments share the judicialization concern, arguments against the power of judges, agamst trial-type procedures, against costly, complex procedures in general. 11 Judge Smith adds to these his own synthesis: all of these complaints about administrative law are right; the currently dominant approach to administrative law is wrong; process should serve substance; and substance should be grounded in the political judgments that properly shape and reflect popular consensus. ${ }^{12}$

Attractive thougli these general themes are, in developing them Judge Smith passes inuch too quickly over two important points: the difficulty of arriving at political consensus, and the importance to political consensus of exactly those processes to which Smith objects. When, in accordance witlı Judge Smitli's plea, we turn to substantive concerns as the touchstone of administrative law, we immediately confront intractable problems in defining what constitutes "good" government and in selecting mechamisms to ensure its accomplishment. While these problems are common to all areas of public law, ${ }^{13}$ they are particularly troublesome for administrative law, which attempts to prescribe decisionmaking processes for the full range of government bureaucracies. These problems do not compel a return to the concepts of administrative process that trouble Judge Smith. They do, however, limit how far we can inove from current concerns and structures.

\section{The Problem of Social Good}

The first problem necessarily posed by our search for substantive guidance is selecting the principles to guide social choice. ${ }^{14}$ Yet the solution to this first problem is impeded by the diversity of private choice orderings; differences as to what we want, what we would give to get it, and under what circumstances, frustrate both efforts to select outcomes for society and efforts to select principles for social choice. Group decisionmaking is not simply individual decisionınaking writ large. Individu-

tional decisionmaking, see generally Diver, The Judge as Political Powerbroker: Superintending Structural Change in Public Institutions, 65 VA. L. REV. 43, 77-106 (1979).

11. Smith, supra note 1 , at $428-29$.

12. Id. at 429-32.

13. See, e.g., Cass, The Meaning of Liberty: Notes on Problems Within the Fraternity, 1 NOTRE DAME J.L. ETHics \& PUB. PoL'Y 777 (1985) (discussing approaches to interpretation of "liberty" in the Constitution).

14. See, e.g., J. Schumpeter, Capitalism, Socialism, ANd Democracy 250-52 (3d ed. 1950); Black, On the Rationale of Group Decision-Making, 56 J. PoL. EcoN. 23 (1948) (implying, in assumption that each member of decisionmaking group can rank options in order of preference so that the orderings are comparable, that some common principles of choice have been reached); Rawls, Justice as Fairness, 67 PHIL. REV. 164 (1958). 
als may make decisions they later regret because the benefit derived from an activity was less or the cost greater than anticipated. ${ }^{15}$ As a general rule, however, we trust individuals to decide which among many possible options for activity each will take. ${ }^{16}$ Each individual gathers, assesses, and acts upon information according to his or her skills and preferences. There seldom is a need to articulate the principles that inform individual choices or the mechanics by which those decisions are made. Although these primciples and mechanisms may be of intense interest, respectively, to philosophers and psychologists, for most purposes of social interaction we are willing to accept each private order of choices as a given, irrespective of the nature of the order or the manner in which it was fashioned. ${ }^{17}$

When social, rather than individual, choices are involved, some order of preference inust be selected for decisions affecting more than one person. Making this selection is simple only in the extremely unlikely event that all persons concerned share identical preferences. The notion of "Pareto efficiency" extracted from the work of Vilfredo Pareto elegantly addresses a subset of situations that come close to this sharedpreference state, suggesting that social decisions are proper if at least one person is benefitted and no one harmed. ${ }^{18}$ The more likely case for a collective decision, however, is that for any contenplated action some persons will beheve they are made better off while others will betieve they are made worse off. Whenever that situation arises, a primciple must be found that permits collective decisionmaking to benefit some persons at the expense of others. Put differently, unless all concerned concur as to which choices are good and which bad, some definition of collective good

15. See March, Bounded Rationality, Ambiguity, and the Engineering of Choice, 9 BELI J. ECON. 587, 593-605 (1978) (indeterminacy of future human preferences, as well as human limitations in foreseeing future consequences of actions, inject uncertainty into efficiency of human decisionmaking).

16. While we impose certain restraints-such as competency and majority-on our faith in individual orderings of choice, paternalistic intervention in people's affairs is in twentieth-century America almost universally viewed as being suited only to unusual circumstances; it is the exception, not the rule. See Regan, Justifications for Paternalism, in Nomos XV: THE LIMITS OF LAW 189 (J. Pennock \& J. Chapman eds. 1974).

17. How these private choices then are treated-favored or disfavored-by legal rules is, of course, a separate issue. See, e.g., Gillette, Commercial Rationality and the Duty to Adjust LongTerm Contracts, 69 MinN. L. REV. 521 (1985) (reluctance of courts to adjust private contracts when changed circumstances reduce value of the choice ordering to one party); see also Burt, Commentary on Schelling's "Enforcing Rules on Oneself," 1 J.L. EcoN. \& ORG. 381 (1985); Schelling, Enforcing Rules on Oneself, 1 J.L. EcoN. \& ORG. 357 (1985) (discussing degree to which private choice orderings are inherently binding on individual will).

18. See V. Pareto, Manuel D'Economie Politique (2d ed. 1927). Pareto's ideal is usefully discussed in many works, including Coleman, Efficiency, Utility, and Wealth Maximization, 8 HoFSTRA L. REv. 509 (1980); Sager, Pareto Superiority, Consent, and Justice, 8 HofsTRA L. REV. 913 (1980). 
is required. ${ }^{19}$

The definition of collective good has been a task pursued over the years by philosophers, economists, pohtical scientists, and lawyers, among others. Despite attention from a considerable number of respected thinkers, no definition has gained consensus. The attempts to crack this chestnut may be grouped in two classes: (1) those seeking to guide action by articulated "first principles," 20 and (2) those looking to soine aggregation of individual choices for guidance.21

Even a lengthy book could not do justice to the group of proposals for defining the social good according to first principles. It is sufficient for present purposes to note that all such proposals founder at a common point: each depends on collective acquiescence in the proponent's views and values. First principles are not logical deductions from einpirical evidence; they are not testable hypotheses. Rather, they are more or less scrupulous elaborations of the proponent's own preferences, and their acceptance consequently depends on the cultural heritage and current circumstances of their audience. ${ }^{22}$ In other words, to the extent first principles enibody shared notions of good they will be embraced; to the extent they do not, they will be rejected.23 Absent universal acceptance of a principle (within the relevant decisionmaking universe), the question

19. See A. Sen, Choice, Welfare, and Measurement 341 (1982) [hereinafter A. Sen, CHO1CE]; Ramachandra, Liberalism, Non-binary Choice and Pareto Principle, 3 THEORY \& DECISION 49 (1972); Sager, supra note 13. See also A. SEN, Collective Choice and Social WelFARE 83-85 (1979) (offering a normative critique of the Pareto principle) (hereinafter A. SEN, Coldective CHOICE]. Unanimity, of course, is possible without shared preferences if the decision to be made is structured in a particular fashion and individuals with divergent preferences agree that one of the possible choices is preferable to any other. Note, too, that the definition of collective good necessary where unanimous choice is not reached may take substantive or procedural form.

20. See, e.g., R. DWORKIN, TAKING RIGHTS SERIousLy (1977); J. RAwis, A THEORY of JUSTICE (1971).

21. See, eg., K. ARrow, Social Choice and Individual Values (2d ed. 1963); R. Dahl, A Preface to Democratic Theory (1956); Bergson, $A$ Reformulation of Certain Aspects of Welfare Economics, 52 Q.J. Econ. 310 (1938).

22. The rich literature critiquing the work of John Rawls, supra note 20, often makes this poimt. See, e.g., A. SEN, CHoICE, supra note 19, at 135-41; Arrow, Some Ordinalist-Utilitorian Notes on Rawls's Theory of Justice, 70 J. PHIL. 245, 252-55 (1973); Hare, Rawls' Theory of Justice, 23 PhIL. Q. 144 (1973), reprinted in READing RAwLS 81 (N. Daniel ed. 1974); Nagel, Rawls on Justice, 82 PHIL. REv. 220 (1973), reprinted in REAding RAWLS, supra at 1.

23. See, e.g., Harsanyi, Can the Maximin Principle Serve as a Basis for Morality? A Critigue of John Rawls's Theory, 69 AM. PoL. SCI. REv. 594, 602 (1975) (doubting applicability of Rawls's theory because rigid first principles incapable of doing justice to complex moral problems); Hart, Rawls on Liberty and Its Priority, 40 U. CHI. L. Rev. 534, 545 (1973) (questioning result, under Rawls's acceptance of liberty as first principle, when people differ as to value of confiicting liberties), reprinted in READING RAwLS, supra note 22, at 230 . Other principles such as those variously proposed by Robert Nozick, Charles Fried, Ronald Dworkin, and Roberto Unger have been criticized on similar grounds. See, e.g., A. SEN, CHorce, supra note 19, at 306-07 (critiquing an aspect of R. NozicK, ANARCHY, STATE AND UTOPIA (1974)). 
remains as to why non-believers should acquiesce in decisionmaking guided by that principle. That proponents of first principles, like adherents to particular religions, have faith in the rightness of their principles is no answer-and at the same time is the only answer to this question.

The second class of principles for social ordering frequently is presented as an alternative that avoids the necessity for the Kierkegaardian leap of faith ${ }^{24}$ on which principles of the first class depend. ${ }^{25}$ The arguinent is that by aggregating individual values we allow eacli individual's preferences to play a role in arriving at the collective decision. True as this is, of itself this faith in the aggregation of individual choices constitutes a first principle subject to contravention by all whose theology of public decisionmaking diverges.

Putting that objection aside, we encounter a second difficulty: some means must be devised for aggregating diverse individual views. Inevitably this calls for another choice among first principles.

One could, in line with some notions of democracy, count unweighted plusses and minuses, each person casting one yes or no vote on every issue. This mechanism has the benefit of theoretical simplicity; one need only identify the relevant participants, define the issue in a fashion permitting binary tabulation, and provide a vehicle for registering individual votes. Of course, for some issues, defining the relevant participants and framing the issue in a mauner suitable for resolution proves difficult, ${ }^{26}$ and there is evidence that the order in which issues are considered as well as the way in which they are framed may influence results. ${ }^{27}$ Moreover, it is possible for individual choices to be ordered in a mauner such that use of the "democratic choice model" and the seriatim voting process results in defeat for any proposed action on a given issue despite the preference of each voter for action over inaction. ${ }^{28}$

The deniocratic model is also criticized for failing to take into ac-

24. See S. KierkegaArd, Afsluttende Uvidenskabelig EFTERSKRIft (Copenhagen 1846) (published in English as CoNCLUding UNSCIENTIFIC PosTCRIPT (1941)).

25. See, e.g., Posner, The Ethical and Political Basis of the Efficiency Norm in Common Law Adjudication, 8 HOFSTRA L. REv. 487 (1980); Posner, Utilitarianism, Economics, and Legal Theory, 8 J. LEGAL STUD. 103, 110-11 (1979).

26. See D. Black, THE THEORY of COMMrTtees AND Elections $146-47$ (1958) (discussing compromise and obstinacy in international negotiation); W. RIKER \& P. ORDESHOOK, AN INTRODuction to Positive Polit:Cal Theory 78-115 (1973).

27. E.g., Levine \& Plott, Agenda Influence and Its Implications, 63 VA. L. Rev. 561 (1977); McKelvey, Intransitivities in Multidimensional Voting Models and Some Implications for Agenda Control, 12 J. ECON. THEORY 472 (1976).

28. See, e.g., D. MUeller, Public Chorce 38-49 (1979) (reviewing the literature on "cycling" under majority rule-that is, the result that when committees are free to redefine the issues proposed, the losers have such high incentives to become part of a winning coalition that the majority shifts in an endless cycle, preventing nonarbitrary choice of winner). 
count the different intensities of individual preferences. ${ }^{29}$ A minority of voters intensely interested in an issue may value outcome $A$ a great deal more than the relatively dismterested majority values outcoine $B$. If we look to individual values to dictate social choices, why rely solely on the nuinber of voters to favor one result rather than on the value those voters place on that and alternative results? Were negotiation ainong the group meinbers possible, it is inore likely that value-weighted votes would reflect consensus than that a majority of unweighted votes would..$^{30}$

If, however, the differing intensity of individual interests is to be taken into account, yet another hurdle is presented. By what metric is mtensity of interest to be judged? A substantial body of literature is devoted to analyzing the difficulties of making interpersonal utility comparisions. $^{31}$ The only convement inedium for indicating intensity of interest is money; but there is considerable basis for doubt that different people with different ainounts of money place the same value on it. ${ }^{32}$ Indeed, discomfort with a "market choice inodel" preinised on dollarweighted votes inay provide the chief impetus for reversion to the democratic choice model. ${ }^{33}$

\section{Principles and Process: Problems in Translation}

Lack of consensus as to a principle for public decisionmaking permeates all discussions of public action. Were such consensus achieved, however, there still would be difficulty making the decisionmaking process conforn to the principle. Agreement on a general choice principle does not completely eliminate the divergence ainong private preferences for outcomes.

29. E.g., Stigler, Economic Competition and Political Competition, 13 PUв. CHOICE 91 (1972).

30. E.g., J. BuChaNAN \& G. Tullock, THE CALCulus OF CONSENT 119-98, 211-22 (1962); A. DOWNS, AN ECONOMIC THEORY OF DEMOCRACY 187-88 (1957). For general discussions of this aspect of collective action, see M. Olson, THE LOGIC OF Collective Action (1965); W. RikeR, THE THEORY OF Polmtical COALITIONS (1962).

31. See, e.g., L. Robbins, AN Essay ON THE Nature and Significance of Economic SCIENCE 138 (2d ed. 1935); A. SEN, CHOICE, supra note 19, at 203-21; Harsanyi, Cardinal Welfare, Individualistic Ethics, and Interpersonal Comparisons of Utility, 63 J. PoL. ECON. 309, 316-21 (1955); Samuelson, Reaffirming The Existence of "Reasonable" Bergson-Samuelson Social Welfare Functions, 44 ECONOM1CA 81 (1977).

32. See G. Stigler, The Theory of Price 51-52 (3d ed. 1966) (discussing "indifference curve" of diminishing marginal utility as quantity of commodity increases); Sen, Personal Utilities and Public Judgements: Or What's Wrong With Welfare Economics?, 89 EcoN. J. 537 (1979).

33. See, e.g., Blum, The Divisible First Amendment: A Critical Functionalist Approach to Freedom of Speech and Electoral Campaign Spending, 58 N.Y.U. L. REv. 1273, 1369-78 (1983); Frug, The Ideology of Bureaucracy in American Law, 97 HARv. L. REv. 1276, 1373-77 (1984); Wright, Money and the Pollution of Politics: Is the First Amendment an Obstacle to Political Equality?, 82 COLum. L. Rev. 609 (1982). 
Principles of the first class are dependent either on universal assent and uniform interpretation or on the coercive power of the principle's proponents. The former is extremely unlikely to occur. Even if all agreed that social decisions should, for instance, maximize benefits to the worst-off class, ${ }^{34}$ itself an improbable outcome, agreement on who is worst-off, how class boundary lines should be drawn, and what choice among several alternatives maximizes benefits to that class would be fortuitous. ${ }^{35}$ Agreement on such ambiguous principles as this "maximin" rule, or on propositions such as "America should have a strong economy," is an insufficient basis for public decisionmaking. Rather, the agreement must extend to relatively detailed determinations derivable from the initial substantive principle. Absent universal concurrence as to the principle's legitimacy and meaning, its utility as a vehicle for controlling public actions must rest on the coercive power of whatever group does agree on those points. Further, the absence of umiversal assent, while necessitating coercive power, also provides a variety of vehicles for compromising and mitigating the coercive power visited upon the dissenting groups by the orthodoxy. ${ }^{36}$

The second group of principles also loses something in translation. The democratic choice model faces serious impediments best captured by Professor Kenneth Arrow's impossibility theorem: democratic decisions that ineet certam basic criteria are not derivable from any process free from arbitrary or undemocratic constraints on social choice. ${ }^{37}$ Even if we are willing to credit whatever choice emerges from decisions that are affected by agenda-setting and other constraints, devising the appropriate choice mechanisn is problematic. The sheer size of the polity and

34. See J. RawLS, supra note 20 , at $152-57$.

35. See, e.g., D. MUeLLER, supra note 28, at 239-41; Hart, supra note 23; Klevorick, Discussion, 64 AM. ECON. REv. 158 (1974).

36. See, e.g., H. PACKer, THe Limits OF THE CRiminal SANCtion 332-42 (1968) (in context of criminal sanctions for behavior (drug use) for which consensus as to external harm is lacking).

37. K. ARRow, supra note 21, at 22-60. Professor Arrow imposes upon the construction of a social welfare function five "reasonable" conditions generally embodying doctrines of citizens' sovereignty and rationality: (1) all logically possible orderings are obtainable from the admissible set of individual choice orderings; (2) the social ordering will respond positively or nonnegatively (i.e., increasing or not decreasing welfare) to alterations in individual values; (3) the choices from a fixed environment of alternatives are independent of alteruatives outside that environment; (4) social choice is not to be imposed upon individuals (i.e., no exterual constraint on social choice); and (5) social choice shall be nondictatorial (i.e., no internal domination). Id. at 22-33. Professor Arrow then determines that a social welfare function satisfying all five conditions leads to a contradiction, and concludes that satisfactory social welfare orderings must compromise one or more of these democratic conditions. Id. at $46-60$.

The criteria Arrow chooses and the significance of the results he obtains are discussed helpfully in A. MacKay, Arrow's Theorem: The Paradox of Social Choice (1980) (combining, for discussion purposes, the fourth and fifth conditions); D. MUELLER, supra note 28, at 185-206; A. Sen, Collective Choice, supra note 19, at 35-55. 
number of public choices to be made imposes the first constraint: everyone's preference cannot, except at insuperable cost, be registered on each matter for which some collective choice is made. ${ }^{38}$ As choices are delegated and issues subject to direct voter decision are bundled, decisions will deviate from the democratic choice model's ideal, even assuming that delegates uniformly attempt to divine and effectuate majority preferences. Accurate information about voter preferences on particular issues cannot easily (at low cost) be had, and the results of delegate elections provide scant guidance on most issues. ${ }^{39}$ More significantly, the incentives of the delegate diverge from uniform implementation of majority preferences, and this divergence increases with the number of decisions made by the delegate, the number of voters the delegate represents, and the heterogeneity of voter outlook..$^{40}$

In large measure, the reason for this is the disparate intensity of voters' interest $\mathrm{m}$ different issues. As noted earlier, a normative objection to the democratic model is that it should reflect intensities of preferences. ${ }^{41}$ Beyond that, a practical objection is that choice mechanisms in fact must reflect such intensities. It is difficult to keep people from acting as though how much they care about an issue matters. In implicit and explicit vote-tradimg, in lobbying and other devices for influencing public decisions, people will reflect the intensity of their interest in specific matters, and delegates will respond. ${ }^{42}$ One response will be to delegate decisionmaking authority further ${ }^{43}$-and each additional delegation decreases the decisionmaker's incentives to ascertain and implement majority preferences.

The market choice model faces similar difficulties. The attempt to maximize social value through the use of payment mechanisms ineets a familiar series of practical objections: under-provision of public goods, free-rider problems in influencing decisions, unequal transaction costs in influencing decisions. ${ }^{44}$ Consider, for example, a contest over a proposed

38. See J. BuchanaN \& G. TUllock, supra note 30 , at $68-69$, 88-96.

39. See Stigler, supra note 29.

40. See J. Buchanan \& G. Tullock, supra note 30, at 109-16; W. Riker \& P. ORDEshook, supra note 26 , at $360-70$.

41. See supra notes $29-30$ and accompanying text.

42. See J. BuchaNAN \& G. TULLOCK, supra note 30, at 55-60; M. Olson, supra note 30, at 141-43; Barro, The Control of Politicians: An Economic Model, 14 PUB. Cholce 19 (1973); Riker \& Brams, The Paradox of Vote Trading, 67 AM. Pol. SCI. REv. 1235 (1973).

43. See, e.g., Aranson, Gellhorn \& Robinson, $A$ Theory of Legislative Delegation, 68 CORNELL L. Rev. 1, 24-26, 30-37 (1982); Peltzman, Toward a More General Theory of Regulation, 19 J.L. \& ECON. 211 (1976); Stigler, The Theory of Economic Regulation, 2 BELL J. ECON. \& MGMT. SCI. 3 (1971).

44. See, e.g., J. Buchanan, The Demand and Supply of Public Goods (1968); A. FeldMaN, Welfare ECONOMics AND SOCIAL ChOICE THEORY 89-210 (1980); R. LUCE \& H. RAifFa, 
shopping mall. The cost of building the mall in diminished value of surroundimg property may exceed its value. But if the value of the mall's benefit is captured by the developer, while its cost is spread across 2,000 nearby homeowners, the cost of aggregating funds for the pro-mall position will be much less than the cost of aggregating the value of the antimall position, and distortion in the data for making the social choice will result. If government is asked to nnake decisions when asymmetric transaction costs inake the economic market an imperfect guarantor of social value, the same probleins exist. Government decisioninakers inight well be instructed to act as surrogates for the zero-cost market, but, absent an obvious market choice, the impedimients to revealing the true dollar votes in the market will produce similar distortions in government action. Instead of a market distortion because of unequal costs in aggregating funds to bid for the property, the result will be a distorted public decision because of unequal costs in aggregating funds to influence the government decisionmaker (e.g., througli lobbying). The same impediments to perfectly functioning inarkets impair perfect market choice government. 45

Whichever principle for social clioice one finds desirable, the implementation is difficult. The difficulty in each case reflects the underlying difference of opinions regarding social choice. We do not lave uniform desires and values. No verbal formula will make that fact disappear. No principle that attempts to evade the ultimate resolution of these underlying differences can produce a yardstick easily applied to observable data. And without such a yardstick, the procedures designed to implement such a principle never can fully succeed. 46

Frustrated by the inability to tailor processes that can be trusted to give effect to a principle, commentators often seek refuge in authority. It is teinpting to posit the existence of an overseer who will spot and reverse deviations from the principle selected. But the suggestion, while tempting, is fatuous. Although many coinmentators, myself included, will

Games and Decisions (1957); Head, Public Goods and Public Policy, 17 Pub. Fin. 197 (1962); Williamson, Transaction-Cost Economics: The Governance of Contractual Relations, 22 J.L. \& EcoN. 233 (1979).

45. See, e.g., G. Tullock, Private Wants, Public Means (1970); Goetz \& McKnew, Paradoxical Results in a Public Choice Model of Alternative Government Grant Forms, in THEORY of Public Cholce 224 (J. Buchanan \& R. Tollison eds. 1972); Posner, Theories of Economic Regulation, 5 Bell J. Econ. \& Mamt. ScI. 335 (1974); Stigler, Free Riders and Collective Action: An Appendix to Theorics of Economic Regulation, 5 BELL J. ECON. \& MGMT. SCI. 359 (1974).

46. See, e.g., A. SEN, CHolce, supra note 19, at 41-73, 226-58; Kennedy, Cost-Benefit Analysis of Entitlement Problems: A Critique, 33 STAN. L. REv. 387 (1981) (noting implicit value judgments in liberal Pareto superiority analyses, and indeterminacy of such analyses when stripped of value judgment); Singer, The Player and the Cards: Nihilism and Legal Theory, 94 YALE L.J. 1, 25-39 (1984) (arguing that legal discourse generally fails to resolve contradictory value choices). 
argue that a given result diverges from a particular principle, the divergence inevitably is judged by the commentator's own lights. The absence of simple, easily applied, substantive principles precludes agreement that a principle has been violated. 47 Any attempt to construct inechanisms to control public decisionmaking thus is hampered by the very difficulty that prompted the attempt to control the decisionmaker: the difficulty of ascertaining departures from the ideal. ${ }^{48}$

\section{Re-Constituting the Process Debate}

Judge Smitl's call for attention to substantive concerns, for the creation of "a coherent rationale for a system of order, justice, and liberty,"49 does not bring us back to a simple, accepted, but teinporarily forgotten notion of the public good. Instead, it forces us to confront the uncomfortable fact that no such notion exists. Witliout it, we limp along-or, as Professor Lindbolm put it, inuddle through ${ }^{50}$ - trying to find "secondbest" criteria to guide our social choices. The intractability of the problems of selecting and implementing principles for public decisioninaking does not mean that there are no criteria for judging the propriety of governmental action. It does mean that no criteria are free froin serious dispute and that no judgment about their application is free froin contravention.

The enterprise Judge Smith would have us undertake-to root administrative law in substantive principle-thus should not be seen as a search for a truly coherent rationale, a principle of global application. Rather, it is the search for partial, usable, but ultimately indefinte criteria to guide decisions. These second-best criteria take a variety of forms. Most often, they are combinations of lialf-formed principles and morefully specified procedures.

The move from idiosyncratic, comprehensive principles to unore broadly accepted, partial guides, then, also moves us away from substance and toward process. Judge Smith inplicitly recoguizes this-he repeatedly invokes the constitutional frainework of our government as the base referent in which arguinents about administrative law should be grounded. ${ }^{51}$ The Constitution, our sacred legal-governmental text, does

47. See Leff, Unspeakable Ethics, Unnatural Law, 1979 DuKe L.J. 1229, 1241 (if each individual's ethical conclusions are unassailable, conflict is inevitable; only if some agreement on ethical evaluation is possible may conflict be avoided).

48. See, eg., Cass, Damage Suits Against Public Officers, 129 U. PA. L. REv. 1110, 1164-79

(1981); Cass, supra note 6.

49. Smith, supra note 1 , at 466.

50. Lindblom, The Science of "Muddling Through," 19 Pub. AD. REv. 79 (1959).

51. E.g., Smith, supra note 1, at 447-50, 457-59. 
contain substantive guidance, providing a mix of first principles in different provisions and amendments. ${ }^{52}$ Its mam concerns, however, are those of process. Unable to agree on substantive outcomes for known issues or to foresee inany future issues, the framers prescribed procedures for resolving various arguments. ${ }^{53}$ The focus of the Constitution, thus, is not entirely supportive of Judge Smith's plea for less concern with process and inore with the substance of government action. Moreover, the procedures set out in the Constitution provide much less help in resolving issues of inter-branch coinpetence than Judge Smith appears to believe and provide less support for some of his views than he would like.

The principal lesson Smith draws from the Constitution is a familiar one: the basic judgments of our society are to be made by politicians through political processes. ${ }^{54}$ From this, Judge Smith intimates, we can deduce the secondary lesson: that judges and judicial processes should play a much smaller role than they now do. The theine on which Smith plays is heard frequently in arguinents over the appropriate allocation of decisional authority. ${ }^{55}$ The appeal to nonjudicial, dennocratic processes

52. See, e.g., Monaghan, Our Perfect Constitution, 56 N.Y.U. L. REv. 353, 361-67 (1981) (discussing theory that Constitution contains both particularized provisions to be applied strictly, and more general provisions to be interpreted in light of modern conditions); Schauer, Must Speech Be Special?, 78 Nw. U.L. REv. 1284, 1305-06 (1983) (the fact that freedom of speech is singled out for protection by Constitution indicates underlying principle that speech is "special" relative to other liberties); Tribe, The Puzzling Persistence of Process-Based Constitutional Theories, 89 YALE L.J. 1063, 1065-67 (1980).

53. See, e.g., Wechsler, The Political Safeguards of Federalism: The Role of The States in the Composition and Selection of the National Government, 54 COLUM. L. REV. 543 (1954) (constitutional procedures designed to accommodate coexistence of states and national government as separate entities).

The dominance of process in the "answers" given by the federal Constitution is plain. What to make of it has been the source of controversy. Some commentators have essayed to build coherent theories of constitutional adjudication around particular process concerns. E.g., J. CHOPER, JUDIcial Review and the National Political. Process: A Functional Reconsideration of THE Role OF THE SuPREME COURT (1980); J. Ely, DemocraCY AND Distrust (1980). Other scholars have stressed the limits of this approach. See, e.g., Brest, Interpretation and Interest, 34 STAN. L. REV. 765 (1982) (critique of Fiss, Objectivity and Interpretation, 34 STAN. L. REV. 739 (1982)); Lupu, Choosing Heroes Carefully, 15 HARv. C.R.-C.L. L. REv. 779 (1980) (reviewing J, ELY, DEMOCRACY AND DISTRUST (1980)); Tribe, supra note 45, at 1067-68 (stressing substantive basis of procedural norms); Tushnet, Darkness on the Edge of Town: The Contributions of John Hart Ely to Constitutional Theory, 89 YALE L.J. 1037 (1980).

The debate over just how much of constitutional adjudication can be decided by reference to process concerns underscores the point relevant here: the substantive moral grounding Judge Smith seeks may be important to resolve many issues of constitutional interpretation, but the process issues he would deemphasize are the central focus of constitntional discourse.

54. See Smith, supra note 1 , at 430 .

55. See, e.g., L. HAND, THe BILI. OF Rights 66-74 (1958); Bork, Neutral Principles and Some First Amendment Problems, 47 IND. L.J. 1, 2-3, 5-6, 10-11 (1971); Monaghan, supra note 45, at 37071; Wechsler, Toward Neutral Principles of Constitutional Law, 73 HARv. L. Rev. 1 (1959). 
as the normal procedures for social decisionmaking is useful because, like motherhood and apple pie, everyone feels comfortable with the concept.

Like the other staple goods, however, there is less agreement on how much is enough. Surely, the Constitution reposes power principally in the political branches. ${ }^{56}$ Just as surely, the Constitution evidences little faitli in pohiticians and political processes. At every turn, tlie document displays concern over what politicians, political associations, and political processes might do. ${ }^{57}$ In large measure, these concerns are reflected in the division of authority among political bodies. The federal government is not omnipotent (not, at least, in the written Constitution), but must sliare power witl the states. ${ }^{58}$ Within the federal government, the President, Senate, and House are constituted to reflect the views of disparate constituencies, each body in some measure checking the others. ${ }^{59}$ Within each legislative house, the constitutionally-authorized rules of procedure further divide political power. ${ }^{60}$ Finally, unless one is prepared to roll the clock back nearly two centuries and re-argue Marbury, ${ }^{61}$ the courts must be given a place of some importance in the constitutional scheme. The Constitution spells out substantive federal limits on the political branclies' autliority, and courts-the most insular, apolitical decisionmaking bodies im America-are entrusted with the obligation to see tliat those limits are respected.62

56. See, e.g., A. Bickel, The Morality of Consent (1975); Hart, The Power of Congress to Limit the Jurisdiction of Federal Courts: An Exercise in Dialectic, 66 HARV. L. REv. 1362 (1953). The debates over the Constitution leave no doubt where the locus of power was thought to be. See M. FarRand, The Framing of the Constitution of the United States 69-195 (1913) (debates predominantly concerned scope and contours of federal legislative and executive power); THE FEDERALIST No. 78, at 491 (A. Hamilton) (B. Wright ed. 1961) ("[T]he judiciary is beyond comparison the weakest of the three departments of power ....").

57. The different facets of this concern have been explored in numerous works, among them: The Federalist Nos. 10, 47, 48 (J. Madison), 51, 63, 68 \& 78 (A. Hamilton); Sunstein, Interest Groups in American Public Law, 38 STAN. L. Rev. 29 (1985); Wellington, The Nature of Judicial Review, 91 YALE L.J. 486 (1982) (discussing role of countermajoritarian safeguards in judicial interpretation of Constitution and statutes).

58. This understanding was made explicit in U.S. Const. amend. $X$.

59. Thus, in the original constitutional scheme, members of the two legislative houses and the President were chosen by three different electoral processes, from constituencies differently configured, and at different times. U.S. CoNST. art. I, $\S \S 2,3 ;$ id., art. II, $\S 1$.

60. See U.S. CoNST., art. I, $\S 5, \mathrm{cl} .2$. The effect of various rules for procedure and committee assignment is discussed in a voluminous literature. See, e.g., R. ARNOLD, CONGRESS AND THE Bureaucracy (1979); R. FenNo, Congressmen IN Committees (1973); D. Mayhew, ConGRESS: The ELECTORAL CONNECTION (1974); Plott, Some Organizational Influences on Urban Renewal Decisions, 58 Am. Econ. Rev. 306 (1968); Ritt, Committees Position, Seniority, and the Distribution of Government Expenditures, 24 PUB. PoL'Y 463 (1976).

61. Marbury v. Madison, 5 U.S. (1 Cranch) 137 (1803).

62. Indeed, among the welter of competing views on constitutional interpretation, this is one of very few points of agreement. See Cass, supra note 13, at 778-90 and works discussed therein. The term "substantive" in the text above is not used to distinguish constraints divorced from process 
The point often is made that judicial control of public decisions is an anomaly in our constitutional scheme. ${ }^{63}$ That point, while instinctively appealing, is sustained by belief and not by logic: the courts' exercise of authority becomes suspect only when extended beyond their proper realm, and defining that realm is, of course, exactly the issue. ${ }^{64}$ If the case is to be made that courts have intruded too far into the domains of other branches of government, it is necessary to spell out tliose respective domains with some precision.

Separating the sphere of decisionmaking appropriate to any of the branches of government from that properly left to the otlier branches long has been problematic. Every attempt to draw clear boundaries within the federal government and between federal and state authority lias failed. The rise and fall of the limited commerce clause, ${ }^{65}$ Lochnerstyle substantive due process, ${ }^{66}$ the nondelegation doctrine, ${ }^{67}$ and $\mathrm{Na}$ tional League of Cities' insulation of traditional state functions from federal predation 68 are some of the inore visible examples of this plienoinenon. Similarly, the effort to define executive functions, as distinct from legislative or judicial functions, $m$ aid of explicating the interbranch division of appointment and removal powers, lias taken courts on an unsteady journey from Myers ${ }^{69}$ and Humphrey's Executor ${ }^{70}$ to Buckley v. Valeo ${ }^{71}$ and the judicial attack on Gramm-Rudman. ${ }^{72}$ Even $I N S$ v.

concerns from constraints that arguably arise from concern over process defects. See, e.g., Sager, Rights Skepticism and Process-Based Responses, 56 N.Y.U. L. REv. 417 (1981); Sandalow, The Distrust of Politics, 56 N.Y.U. L. REv. 446 (1981).

63. E.g., A. Bickel, The Least DaNGerous Branch 16-23 (1962); L. HaND, supra note 55, at 66-74; Bork, supra note 55, at 8 (choice of "fundamental values" by Court not justifiable); Wechsler, supra note 55 , at $2-20$.

64. See Cass, supra note 13, at 788 (simple majority goverance preference misleading; but narrower form of preference is unhelpful in resolving roles of legislature and court); Sager, supra note 62, at 442 (Constitution too complex to assume a simple underlying value of majoritarianism).

65. Compare Katzenbach v. McClung, 379 U.S. 294 (1964), and Umited States v. Darby, 312 U.S. 100 (1941), with Carter v. Carter Coal Co., 298 U.S. 238 (1936), and Hammer v. Dagenhart, 247 U.S. 251 (1918).

66. Compare Williamson v. Lee Optical, Inc., 348 U.S. 483 (1955), and Nebbia v. New York, 291 U.S. 502 (1934), with Adkins v. Children's Hospital, 261 U.S. 525 (1923), and Lochner v. New York, 198 U.S. 45 (1905). See generally McCloskey, Economic Due Process and the Supreme Court: An Exhumation and Reburial, 1962 SuP. CT. REv. 34.

67. Compare FCC v. RCA Communications, 346 U.S. 86 (1953), and Yakus v. United States, 321 U.S. 414 (1944), with Schechter Poultry Corp. v. United States, 295 U.S. 495 (1935), and Panama Refining Co. v. Ryan, 293 U.S. 388 (1935).

68. Compare Garcia v. San Antonio Metropolitan Transit Auth., 105 S. Ct. 1005 (1985), with National League of Cities v. Usery, 426 U.S. 833 (1976).

69. Myers v. United States, 272 U.S. 52 (1926).

70. Humphrey's Executor v. United States, 295 U.S. 602 (1935).

71. 424 U.S. 1 (1976). Part IV of the Court's opinion in Buckley, id. at 109-43, declared that the members of the Federal Election Commission (FEC) performed functions that could be classified under four different headings: those in aid of legislation, those that were themselves quasi-legislative, 
Chadha, ${ }^{73}$ which Judge Smith gingerly praises as a step away from judicialization and toward "true congressional policy oversight," 74 reveals the difficulty of efforts to separate the arena of one branch from that of another: if Congress can authorize executive officials to make policy with hittle or no real guidance, why cannot Congress retain a relatively low-cost check-the legislative veto-over that policymaking process? Declaring the act "legislative" or "executive" may convey the speaker's decision, but it does not present a clear reason derived from exphicit constitutional principle. ${ }^{75}$

It should not be surprising that these efforts to resolve separation-offunction issues seem more the products of intuition than of logical derivation from definite premises: the Constitution sinply does not provide clear guidance on these problems-at least not at the "edges" where the issues arise. The legislative and executive branches both have roles to play with respect to most governmental functions, and the roles are not sharply distinguished in the text. The roles are not, of course, entirely interchangable; one does get a feel for the different behavior expected of these branches. The point, however, is that all one has in this area is feeling, and feelings about what legislators and adininistrators should be doing inevitably differ. ${ }^{76}$

So it is with defining the judicial role. Judges differ from legislators and administrators more than other officials diverge one from the

those that were quasi-judicial, and those, such as initiating enforcement actions, that were executive. Only the first function clearly could be delegated to agents of the legislature, and the last function clearly had to be performed by "Officers of the United States" under U.S. CoNST, art. II, § 2, cl. 2. The Constitution requires these officers to be appointed presidentially (with senatorial consent) or administratively (by Department heads). The Court therefore found the legislative involvement in the appointment of FEC members unconstitutional. Buckley, 424 U.S. at 140.

72. Bowsher v. Synar, 54 U.S.L.W. 5064 (1986) (finding the delegation of certain powers to the Comptroller General under the Gramm-Rudman-Hollings Deficit Reduction Act (formally titled the Balanced Budget and Emergency Deficit Control Act of 1985, Pub. L. No. 99-177, 99 Stat. 1037 (1985)) unconstitutional given the executive nature of the functions in issue and the previously adopted legislation authorizing congressional participation in removal (for cause) of the Comptroller).

73. 462 U.S. 919 (1983) (holding legislative veto provision of Immigration and Nationality Act unconstitutional).

74. Smith, supra note 1 , at 451 (emphasis in original). Judge Smith does immediately observe that Chadha might be regarded from different vantage points either as increasing or decreasing judicialization of administrative law. See id. at $451 \mathrm{n} .81$ (explaining that by "true congressional policy oversight" the author does not mean reversal of particular executive decisions or review of regulatory and procedural minutiae).

75. See Elliott, INS v. Chadha: The Administrative Constitution, the Constitution, and the Legislative Veto, 1983 SuP. CT. REv. 125, 131-47; Strauss, Was There a Baby in the Bathwater? $A$ Comment on the Supreme Court's Legislative Veto Decision, 1983 DuKE L.J. 789, 794-801.

76. Compare Aranson, Gellhorn \& Robinson, supra note 43, with Mashaw, Prodelegation: Why Administrators Should Make Political Decisions, 1 J.L. EcoN. \& ORG. 81 (1985). 
other. ${ }^{77}$ But defining how courts should reach decisions, what principles they should employ to implement the Constitution, or how much they should defer to legislators and administrators is no easier than separating legislative from administrative functions. Judges and scholars im constitutional and administrative law have fought over these lines for years in a manner reminiscent of the First World War's Western Front: using all the resources at their command, the combatants emerge from their trenches, gam or lose a few yards, settle imto new trenches, reemerge for another fight, and usually end the second skirmish close to their original positions. ${ }^{78}$

The vagueness of the substantive constitutional provisions most often at issue-their text, history, and motivating principles are all subject to conflicting construction in substantial ineasure ${ }^{79}$-ineluctably leads to debate over the role courts play in constitutional adjudication, and similar problems pervade statutory adjudication. ${ }^{80}$ How far does the due process clause tie the government's hands in structuring procedures for terminating welfare benefits or government employment? ${ }^{81}$ Does the

77. Judges, even where elected, are insulated froin many forces that operate relatively freely on other government actors, and respond to incentives that have hittle impact on other government decisionmakers. See, e.g., B. Cardozo, The Nature of THE Judicial Process (1921); Fuller, The Forms and Limits of Adjudication, 92 HARv. L. REv. 353, 365, 381-93 (1978); Landes \& Posner, The Independent Judiciary in an Interest-Group Perspective, 18 J.L. \& EcoN. 875 (1975).

78. See, e.g., Cass, supra note 13, at 778-90; Brest, supra note 53; Greenawalt, The Enduring Significance of Neutral Principles, 78 Colum. L. Rev. 982 (1978); Grey, The Constitution as Scripture, 37 STAN. L. REv. 1 (1984); Lupu, Constitutional Theory and the Search for the Workable Premise, 8 U. DAYTON L. REv. 579 (1983) (deploring academic "inbreeding" in recent constitutional theory); Monaghan, supra note 52, at 361-74; Schauer, An Essay on Constitutional Language, 29 UCLA L. REv. 797, 812-21 (1982); Tushnet, Anti-Formalism in Recent Constitutional Theory, 83 MICH. L. REV. 1502, 1503-08 (1985) (tracing formalist-antiformalist debate over role of judicial review in constitutional law).

79. See Brest, The Misconceived Quest for the Original Understanding, 60 B.U.L. REV. 204 (1980); Schauer, Authority and Indeterminacy, in Nomos XXIX: AuThORITY REvisITED (J. Pennock \& J. Chapman eds. 1987) (forthcoming); Shiffrin, The First Amendment and Economic Regulation: Away From a General Theory of the First Amendment, 78 Nw. U. L. REv. 1212 (1983) (speech interacts with society in too complex a manner for adequate single theory of first amendment to exist); Westen, The Empty Idea of Equality, 95 HARV, L. REv. 537, 559-96 (1982).

80. See, e.g., G. Calabresi, A Common Law for the Age of StatuTes (1982) (proposing that courts undertake to update obsolete statutes, as they behave toward obsolete precedent); Diver, Statutory Interpretation in the Administrative State, 133 U. PA. L. REV. 549, 551-67 (1985) (describing role of competing independent theories of interpretation of statutes delegating authority to agencies); Dworkin, Law as Interpretation, 60 TEX. L. REv. 527 (1982); Easterbrook, Statutes' Domains, 50 U. CHI. L. REv. 533 (1983) (discussing means of determining whether a statute is applicable, as logically preliminary question to construction of statute); Fish, Working on the Chain Gang: Interpretation in Law and Literature, 60 TEx. L. REv. 551 (1982); Weisberg, The Calabresian Judicial Artist: Statutes and the New Legal Process, 35 STAN. L. Rev. 213 (1983) (comment on G. CALABRESI, supra).

81. See Cleveland Bd. of Educ. v. Loudermill, 105 S. Ct. 1487 (1985); Bishop v. Wood, 426 U.S. 341 (1976); Mathews v. Eldridge, 424 U.S. 319 (1976); Goldberg v. Kelly, 397 U.S. 254 (1970). 
Constitution command a judicial remedy for uncompensated government interference with private rights?82 How much authority does the National Labor Relations Act grant the NLRB to interpret its own statutory mandate? ${ }^{83}$ Without clear and easy answers to questions such as these, it is naive to think that agreement can be reached as to the right amount of judicial intrusion into government decisionmaking. Courts affirm the overwhelming majority of administrative decisions that come before them. ${ }^{84}$ Judge Smith, among others, would have the percentage of affirmances rise still more; other commentators express the opposite preference. ${ }^{85}$ There is little basis for belief that any clear ground for resolution of this difference awaits discovery if only we will look for it.

This does not condemn us to the ultra-realist view of law as determined only by wliat the judge ate for breakfast. ${ }^{86}$ Even without clear principles and easy answers, there are some matters on which consensus emerges. If the hard cases argued about in law school still elude solution, some cases in nearly every substantive area nonetheless have become easy. ${ }^{87}$ No one today will argue seriously that criminal punishment for criticisin of the incumbent administration, or exclusion of blacks or Jews from government service, could pass constitutional muster.

For many inquiries, even when substantive consensus remains elusive, consensus does emerge on the appropriate decisionmaking process. As with substantive problems, difficult issues remain, but there often is general agreement on certain paradigm cases. For creation of everyday positive law, as for Constitution-making, procedural consensus frequently is achieved inore readily than substantive concord. In some ineasure, process agreement is easier than substantive agreement because

82. See Bush v. Lucas, 462 U.S. 367 (1983); Chappell v. Wallace, 462 U.S. 296 (1983); Bivens v. Six Unknown Named Agents, 403 U.S. 388 (1971).

83. See NLRB v. Financial Inst. Employees, Local 1182, 106 S. Ct. 1007 (1986); NLRB v. International Longshoremen's Ass'n, 105 S. Ct. 3045 (1985); NLRB v. Action Automotive, Inc., 105 S. Ct. 984 (1985); NLRB v. Hearst Publications, Inc., 322 U.S. 111 (1944).

84. See Robinson, The Judicial Role, in Communications For Tomorrow 415, 443 (G. Robinson ed. 1978) (finding an eighty percent affirmance rate for FCC decisions during a time of perceived judicial activism on communications policy issues); see also Gardner, Federal Courts and Agencies: An Audit of the Partnership Books, 75 CoLUM. L. REv. 800 (1975) (empirical examination of judicial review of agency decisions in 1974; agencies affirmed in sixty-five percent of cases, apparent deference accorded agency determinations in fifty-two percent of cases).

85. E.g., Frug, supra note 33. See also Stewart \& Sunstein, Public Programs and Private Rights, 95 HARV. L. REV. 1193 (1982) (advocating greater judicial inquiry into a class of administrative actions where public values are at stake); Sunstein, Deregulation and the Hard-Look Doctrine, 1983 SUP. CT. REv. 177 (same). Cf. Michelman, Politics and Values or What's Really Wrong with Rationality Review?, 13 CREIGHTON L. REv. 487 (1979) (similar argument with respect to constitutional review of legislation).

86. E.g., Llewellyn, A Realistic Jurisprudence-The Next Step, 30 CoLUM. L. REv. 431 (1930) (conceptualizing law as engine having purposes, not values in itself).

87. See Schauer, Easy Cases, 58 S. CAL. L. REv. 399, 408-14 (1985). 
people make different (and mutually optimistic) predictions about the probable outcome of a given process. ${ }^{88}$ In some measure, process agreement suggests that most people value the use of certain procedures in particular circumstances. ${ }^{89}$

Judge Smith rightly notes that judges and lawyers often prefer clearly specified forms of proceeding, many times trial-like procedures, when popular consensus favors less formal, less structured, and less judicial procedures. But specified procedures, and trial-type procedures in particular, serve a function apart from making lawyers comfortable and important: formal procedures operate as a brake on admmistrative discretion..$^{90}$ There often is consensus, popular as well as legal, that formal administrative process is advisable precisely because there is distrust of administrators. The Defense Department contracting officers' hands are tied by formal process requirements to prevent favoritism and corruption. ${ }^{91}$ So, too, distrust of police officers' unbridled discretion is the reason these officials must secure warrants, give warnings, volunteer information on rights to the accused, and so on. ${ }^{92}$

What Judge Smith overlooks in his attack on "proceduralism" is the degree to which the mistrust so evident in these examples is endemic, describing a general attitude toward administrative officials at all levels. No one appreciates "red tape," the synonym for undue bureaucratic formalism. Few people, however, want to forsake a government of law in

88. A similar proposition lies at the lieart of much recent work concerning litigants' decisions to settle or try cases, the latter decision represented largely as the product of parties' optimism. See, e.g., Cooter, Marks \& Mnookin, Bargaining in the Shadow of the Law: A Testable Model of Strategic Behavior, 11 J. LEGAL STUD. 225 (1982); Priest \& Klein, The Selection of Disputes for Litigation, 13 J. LEgAL STUD. 1 (1984).

89. See, e.g., J. Thibaut \& L. Walker, Procedural Justice: A Psychological ANalySIS (1975); Mashaw, Administrative Due Process: The Quest for a Dignitary Theory, 61 B.U.L. REv. 885 (1981); Michelman, Formal and Associational Aims in Procedural Due Process, in NomOs XVIII: Due Process 126 (J. Chapman \& V. Pennock, eds. 1977); Saphire, Specifying Due Process Values: Toward a More Responsive Approach to Procedural Protection, 127 U. PA. L. REv. 111 (1978); Summers, Evaluating and Improving Legal Processes-A Plea for "Process Values," 60 CORNELL L. REV. 1 (1974).

90. See Stewart, The Reformation of American Administrative Law, 88 HARV. L. REv. 1667, 1679-81, 1711 -60 (1975); see also K. DAvis, DiSCRETIONARY JUSTICE (1969) (exploring possibilities for controlling, but preserving, administrative discretion).

91. Federal government contract regulations are described in R. NASH \& J. CIBINIC, FEDERAL Procurement LAW (3d ed. 1977). For a discussion of the general problem of corruption, see Banfield, Corruption as a Feature of Governmental Organization, 18 J.L. \& EcoN. 587 (1975); Rottenberg, Comment, 18 J.L. \& ECoN. 611 (1975) (commenting on Banfield, supra).

92. Various legal constraints on police behavior are discussed in Y. KAMISAR, W. LAFAVE \& J. ISRael, Modern Criminal Procedure (5tl ed. 1980). See also A. ReIss, The Police and the Public (1971); Banfield, supra note 91; Reder, Citizen Rights and the Cost of Law Enforcement, $3 \mathrm{~J}$. LEGAL STUD. 435 (1974) (economic analysis). 
favor of a government entirely "of men."93 Judge Smith's confidence that increased discretion in officialdom-legislative and administrative alike-is preferable to increased, judicially monitored formalism typifies the view of officials in power at any given time. Personal knowledge of current officeholders' ability and integrity gives me little basis to differ from Judge Smith's confidence. The procedures with which he is concerned, however, seem to me the inevitable concomitant of a large bureaucracy, not easily monitored, necessarily making each day thousands of decisions as to which our divergent preferences provide no clear socially preferred outcome. Just as our inability to agree on substance often requires that administrative decisionmakers be given discretion or no job at all, ${ }^{94}$ our distrust of the manner in which that discretion will be exercised mandates procedural constraints on administrators. ${ }^{95}$ One can, of course, ask that administrative errors be corrected politically-by changing administrations or by rewriting legislation. Both correctives, however, are blunt instruments, ill-suited to the minutiae of administrative life. Just as pimples may be cured by decapitation or attacked by legislatively mandated cleansing procedures separately directed at each blemish as it occurs, administrative error can be checked by blunt political means. Yet, if pimples are the expected accompaniment of adolescence and administrative errors the predictable by-product of administrative discretion, general, modest procedural precautions seem the more sensible approach to these problems.

93. The phrase "government of laws and not of men" is credited to John Adams, from MASs. CONST. of 1780, Declaration of Rights, art. 30.

94. See R. Cass, Revolution in the Wasteland $42-43$ (1981); Aranson, Gellhorn \& Robinson, supra note 43, at 57.62; Fiorina \& Noll, Voters, Legislators and Bureaucracy: Institutional Design in the Public Sector, 68 AM. Econ. REv. 256, 258-59 (1978) (as legislative programs administered under delegations to agencies become subject to distributive politics, they become objects of political consensus rather than dispute); Mashaw, supra note 76, at 98-99 (broad delegations can improve responsiveness to public interests).

95. The procedural constraints we impose, of course, need not take the form of trial-type procedures. The Civil Service laws, 5 U.S.C. $\$ \S 3301-3397$ (1982 \& Supp. II 1984), provide one important process constraint (a system of competitive examination and certification to insure civil servant ability), that is clearly tied to disbelief that administrative officials' behavior (specifically, their personnel decisions; but by implication also their substantive decisions) mirrors Congress's objectives. Another, different, sort of procedural constraint is 1llustrated by the Social Security Administration's (SSA) "grid" system, 20 C.F.R. pt. 404, subpt. P, app. 2 (1985) (mechanical four-variable test of disability under Social Security Act), instituted as a mechanism for checking the discretion of subordinate SSA officials. See Heckler v. Campbell, 461 U.S. 458 (1982); J. MaSHaw, BureauCratic Justice: Managing Social Security Disability Claims 49-168 (1983); Diver, The Optimal Precision of Administrative Rules, 93 YALE L.J. 65, 88-92 (1983). 


\section{CONCLUSION}

Viewed from this vantage, Judge Smith has seen, not the twilight of administrative law, but merely the haze through which its rays must be filtered. Courts can lose sight of the fact that other branches have important roles in governance. Procedural concerns can deflect attention from important substantive issues. These pathologies, however, should not be taken as proof that the current judicial involvement and procedural orientation in administrative law are undesirable. Consensus on substantive issues is hard to come by. And that, in a nutshell, is why administrators, judges, and formal procedures play the roles they now do. 